OPEN ACCESS

Edited by:

Stella Koutros,

National Cancer Institute

(NIH), United States

Reviewed by:

Joe Shearer,

National Cancer Institute

$(\mathrm{NIH})$, United States

Wagner Ricardo Montor,

Santa Casa de São

Paulo, Brazil

*Correspondence:

H. Dean Hosgood

dean.hosgood@einstein.yu.edu

Specialty section:

This article was submitted to

Cancer Epidemiology

and Prevention,

a section of the journal

Frontiers in Oncology

Received: 30 January 2018

Accepted: 23 March 2018

Published: 16 April 2018

Citation:

Hosgood HD, Gunter MJ, Murphy N,

Rohan TE and Strickler HD (2018)

The Relation of Obesity-Related

Hormonal and Cytokine Levels

With Multiple Myeloma and

Non-Hodgkin Lymphoma.

Front. Oncol. 8:103

doi: 10.3389/fonc.2018.00103

\section{The Relation of Obesity-Related Hormonal and Cytokine Levels With Multiple Myeloma and Non-Hodgkin Lymphoma}

\author{
H. Dean Hosgood ${ }^{1 *}$, Marc J. Gunter ${ }^{2}$, Neil Murphy², Thomas E. Rohan' \\ and Howard D. Strickler ${ }^{1}$
}

'Department of Epidemiology and Population Health, Albert Einstein College of Medicine, Bronx, NY, United States,

${ }^{2}$ Section of Nutrition and Metabolism, International Agency for Research on Cancer, World Health Organization, Lyon, France

This article presents the first detailed overview of the mechanisms that may underlie the relation of obesity with B-cell non-Hodgkin lymphomas (NHLs) and multiple myeloma (MM). Epidemiologic studies, including meta-analyses of prospective cohorts, have reported that the risks of $\mathrm{NHL}$ and $\mathrm{MM}$ are significantly increased in obese, relative to normal weight, women and men. Accumulating experimental and clinical evidence suggests that inflammatory cytokines, hyperinsulinemia, and sex hormones could play a role in the association of obesity with B-cell NHL and MM carcinogenesis. There is, however, a paucity of data published from appropriate large prospective cohort studies, and studies concurrently measuring these correlated factors, to formally determine the likely biologic factors driving the relationship of obesity with $\mathrm{NHL}$ and MM. Additional strengths and weaknesses of the current literature, as well as study design issues that need to be considered in conducting these studies, such as the exclusion of type 2 diabetics or postmenopausal women using hormone therapy, are discussed.

Keywords: non-Hodgkin lymphoma, multiple myeloma, inflammation, hyperinsulinemia, sex hormones

\section{INTRODUCTION}

Hematopoietic malignancies originating from B-cell lymphocytes include each of the major nonHodgkin lymphoma (NHL) subtypes, namely, diffuse large B-cell lymphoma (DLBCL), follicular lymphoma (FL), and chronic lymphocytic leukemia (CLL), as well as multiple myeloma (MM). NHL and $\mathrm{MM}$ are the two most common hematologic malignancies in the United States, with a combined total of approximately 100,000 new cases per year (1). However, there are few well-established risk factors for B-cell NHL beyond male gender, African ancestry, family history, viral infection and diminished immune function, and African ancestry and family history for MM (2-5).

A number of studies, including several meta-analyses, have found significant positive associations between obesity and risk of NHL and MM, adding to the well-known associations of obesity with risk of several common solid tumors (6-8). The International Agency for Research on Cancer (IARC) has deemed the strength of evidence linking adiposity with MM and DLBCL to be sufficient and suggestive for all NHL (9). Accumulating experimental and clinical evidence suggests that inflammatory cytokines, hyperinsulinemia, and sex hormones could play a role in the association of obesity with B-cell NHL and MM carcinogenesis. To date, the associations of 
these factors with NHL and MM risk have not been concurrently evaluated in appropriate large, long-term prospective cohort studies. Such studies are needed to elucidate the association of these factors with risk of hematopoietic malignancies, especially as circulating levels of these factors are correlated with each other. Furthermore, most of the existing epidemiological studies have not accounted for type 2 diabetes or the use of diabetes medications, even though the biologic connection between obesity and these molecular pathways may be altered by diabetes treatment and potentially by type 2 diabetes itself. Likewise postmenopausal women using hormone therapy (HT) should be excluded from such studies, as oral estrogens alter circulating levels of many of these obesity-related factors. Furthermore, stronger and more consistent associations with cancer risk would be expected if the obesity-related downstream molecular pathways underlying obesity's relation with MM and B-cell NHL were directly assessed as exposure variables rather than adiposity itself. While a number of review papers regarding obesity-related cancer have been published (10-18), to the best of our knowledge this article represents the first detailed overview of the mechanisms that may underlie the relation of obesity with hematologic malignancies.

\section{THE RELATIONSHIP OF OBESITY WITH B-CELL LYMPHOMAS AND MM}

The relation of hematological malignancies with obesity has been evaluated extensively $(6,19)$, including in a number of large cohort studies (Table 1). In 2007, for example, prospective analysis of the National Institutes of Health-American Association of Retired Persons (NIH-AARP) Diet and Health Study $(n=473,984)$ observed that those with a body mass index $(B M I) \geq 35 \mathrm{~kg} / \mathrm{m}^{2}$ had an increased risk of NHL [relative risk $(R R)=1.29 ; 95 \%$ confidence interval $(C I)=1.02-1.64]$ compared with individuals with a normal BMI (i.e., $18-25 \mathrm{~kg} / \mathrm{m}^{2}$ ) (19). In 2011, Larsson and Wolk critically reviewed prospective studies of the NHL-obesity association (6). Among the 16 NHL studies ( $n=17,291$ cases) that had been conducted up until that time, a meta-analysis showed that a $5 \mathrm{~kg} / \mathrm{m}^{2}$ increase in BMI was associated with a $7 \%$ increased risk of NHL $(\mathrm{RR}=1.07 ; 95 \% \mathrm{CI}=1.04-1.10)$, which was primarily restricted to DLBCL $(\mathrm{RR}=1.13 ; 95 \% \mathrm{CI}=1.02-1.26)$ (6). However, there was no statistically significant heterogeneity in the subtype-specific associations, and thus the association of obesity with NHL may include additional NHL subtypes. These findings did not differ by gender and were not affected by adjustment for physical activity, or whether height and weight were directly measured or provided by self-report. Since publication of Larsson and Wolk's review, an additional four prospective cohort studies have evaluated the association between obesity and NHL risk (20-23). In the Women's Health Initiative (WHI) cohort study, with 1,123 incident NHL cases (in 158,975 postmenopausal women), Kabat et al. observed that women in the highest quartile of weight and of BMI at age 18 had an increased risk of NHL (21). Furthermore, in the Cancer Prevention Study II (CPS II), Patel et al. observed an increased risk of NHL associated with obesity ( $\geq 30$ versus

TABLE 1 | Characteristics of prospective cohort studies evaluating the risk of non-Hodgkin lymphoma (NHL) associated with obesity.

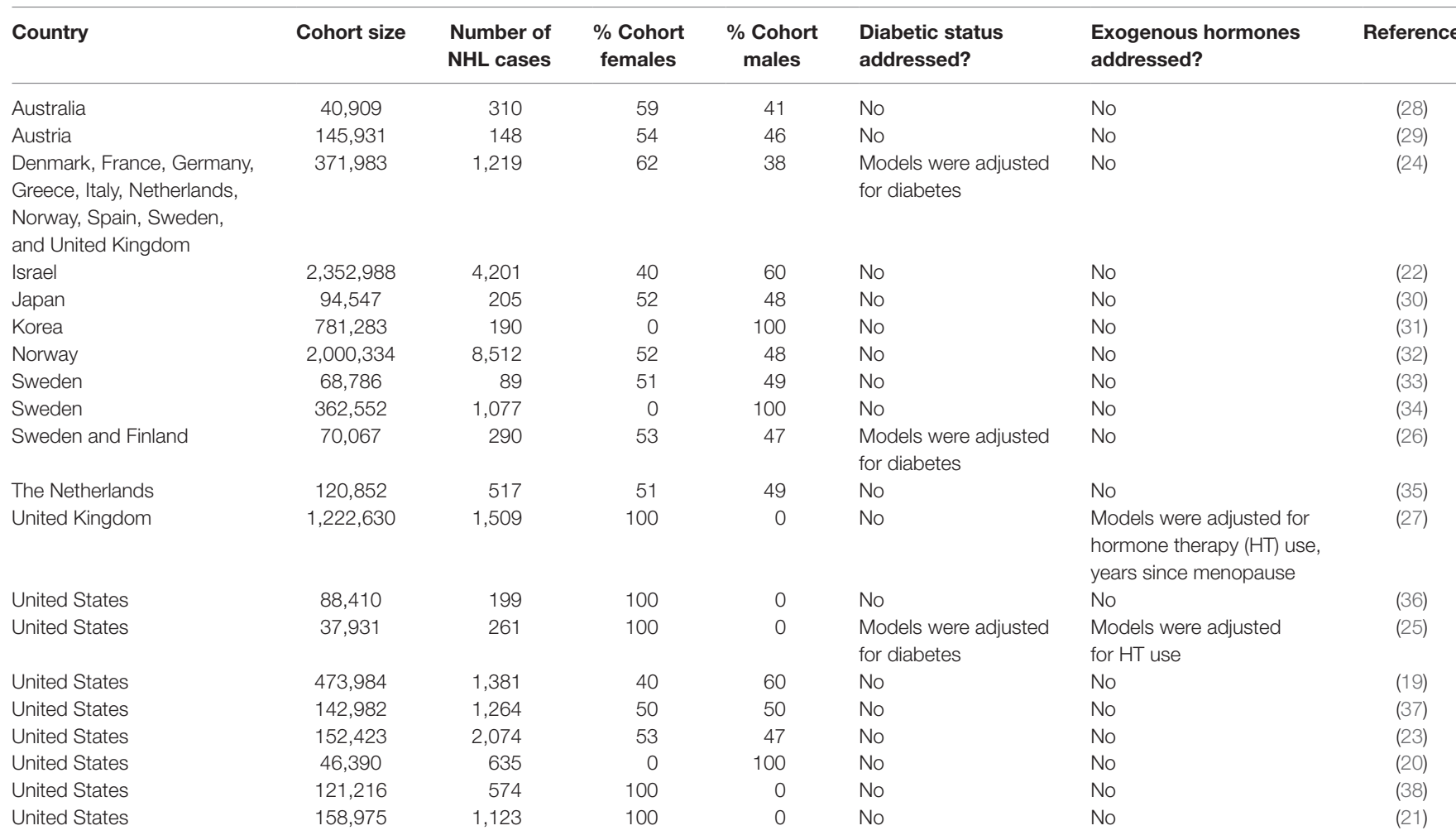


$18.5-<25 \mathrm{~kg} / \mathrm{m}^{2}$ ) in their investigation with 2,074 incident NHL cases (in 152,423 men and women) (23). The other two recent prospective studies also found significant positive associations between obesity and NHL risk (20, 22). However, out of a current total of 22 prospective cohort studies, only 3 studies took into account the presence or absence of diabetes in the analyses (24-26). These studies adjusted their analyses for diabetic status (24-26), raising the possibility that many of the reported associations, while statistically significant, may be attenuated due to the inclusion of type 2 diabetics and pre-diabetics (see Section "Design Considerations for Studies of Obesity-Related Hormones and Adipocytokines in the Etiology Studies of Cancer" regarding study design considerations). Only 2 of the 22 studies accounted for the use of HT or menopause status $(25,27)$, raising similar considerations of possibly attenuated associations. After adjustment for both diabetes and HT, Cerhan et al observed a 2.7 -fold increased risk (95\% CI $=1.2-6.0)$ of B-CLL and high BMI $\left(\geq 28.3 \mathrm{~kg} / \mathrm{m}^{2}\right)$ at age 50 (25).

Multiple myeloma and obesity have similarly been studied in a number of prospective cohort studies (39). The NIH-AARP study observed that each $5 \mathrm{~kg} / \mathrm{m}^{2}$ increase in BMI was associated with a $10 \%$ increased risk of $\mathrm{MM}$ (hazard ratio $=1.10 ; 95 \%$ CI $=1.00-1.22)(40)$, and Wallin and Larsson's meta-analysis found a significantly increased risk of $\mathrm{MM}$ associated with being overweight $(\mathrm{RR}=1.12,95 \% \mathrm{CI}=1.07-1.18)$ or obese $(\mathrm{RR}=1.21,95 \% \mathrm{CI}=1.08-1.35)$, based on 15 cohort studies (39). No evidence of gender differences in these associations was observed, and none of the included studies accounted for diabetic status or HT use, either through statistical adjustment or inclusion/exclusion criteria. A recent pooled analysis in the International Multiple Myeloma Consortium (IMMC), which involved eight case-control studies, found that a $5 \mathrm{~kg} / \mathrm{m}^{2}$ increase in BMI was associated with a $9 \%$ increased risk of adult $\mathrm{MM}$ [odds ratio $(\mathrm{OR})=1.09,95 \% \mathrm{CI}=1.04-1.14$ ] $(41)$, but only when individuals were overweight or obese in both early and later adulthood, suggesting that risk is influenced only by persistently high adiposity.

As mentioned earlier, IARC has deemed the strength of evidence linking adiposity with MM and DLBCL to be sufficient, and suggestive for all NHL (9). The major focus of future investigation increasingly needs to be on the molecular mechanisms underlying the association of obesity with MM and NHL (especially DLBCL).

\section{THE RELATIONSHIP OF INFLAMMATORY CYTOKINES WITH B-CELL LYMPHOMAS AND MM}

Obesity is correlated with chronically high levels of several cytokines (produced primarily by adipose tissues), which play a role in chronic inflammatory states. These cytokines include tumor necrosis factor alpha (TNF $\alpha)$, IL6, IL10, as well as C-reactive protein (CRP). In relation to CRP, recent data suggest that CRP may have pleomorphic immune activity in addition to its well-known role as a biomarker of inflammation (8).
Dysregulation of the immune system is a hallmark of NHL, and laboratory studies of cytokines and hematopoietic malignancies have particularly focused on $\mathrm{TNF} \alpha$ given its pivotal role in initiating inflammatory responses. $\mathrm{TNF} \alpha$ regulates the immune response through activation of the nuclear factor kappa beta transcription factor, leading to the production of pro-inflammatory cytokines, including IL6 (42), which in turn can induce B-cell production of IL10 (43). Moreover, each of these cytokines promotes B-cell proliferation and has antiapoptotic activity (44-46). Additional members of the TNF superfamily include CD27 and CD30, which are expressed on B lymphocytes and promote lymphocyte survival and proliferation $(47,48)$. Experimentally, TNF $\alpha$ has also been shown to act as a tumor growth factor for chronic B-cell malignancies (49), promoting the survival and proliferation of malignant cells $(44,45)$.

The relationship between cytokine levels and risk of B-cell lymphoma has been quantified in several large, well-established prospective cohorts including WHI $(50,51)$, the Prostate, Lung, Colorectal, and Ovarian (PLCO) Cancer Screening Trial (52, 53), the European Prospective Investigation into Cancer and Nutrition Study (EPIC) (54), and the Multi-Ethnic Cohort (MEC) (55). WHI evaluated 11 cytokines (IL1b, IL2, IL4, IL5, IL6, IL10, IL12, IL13, TNF $\alpha$, IFNc, and GM-CSF) and found that subsequent risk of incident B-cell NHL in postmenopausal women (491 cases, 491 controls) was associated primarily with high levels of TNF $\alpha$ and IL10: ORs per doubling in serum cytokine concentration were $1.22(95 \% \mathrm{CI}=1.07-1.38)$ for $\mathrm{TNF} \alpha$ and 1.09 (95\% CI $=1.04-1.15)$ for IL10 (51). MEC reported similar findings (55). Selected cytokines (IL4, IL6, IL10, and TNF $\alpha$ ) and other soluble markers of immune activation [soluble TNF receptor 1 (sTNF-R1), sTNF-R2, CRP, and sCD27] were measured in PLCO in a study of 297 incident NHL cases and 297 individually matched controls (52), finding NHL risk in this study was positively associated with sTNF-R1 $\left(P_{\text {trend }}=0.02\right)$ and sCD27 $\left(P_{\text {trend }}<0.0001\right)(52)$. A second study in PLCO showed positive associations of NHL with B-cell-attracting chemokine $1\left(P_{\text {trend }}=1.0 \times 10^{-6}\right)$, sTNF-R2 $\left(P_{\text {trend }}=1.1 \times 10^{-6}\right)$, and soluble vascular endothelial growth factor receptor $2\left(P_{\text {trend }}=0.0005\right)$ (53). Consistent with these results, positive associations of sCD27 and sCD30 with risk of NHL were recently also reported by the Alpha-Tocopherol, Beta-Carotene Cancer Prevention (ATBC) Study (56) and WHI (50). Overall, it would appear that relatively high levels of prediagnostic pro-inflammatory cytokines increase risk of NHL development. However, mediation analyses to estimate the proportion of the obesity-NHL that may be causally associated with inflammatory factors is warranted.

For MM, in contrast, there remains a paucity of similar studies of cytokines and CRP $(57,58)$. Furthermore, no studies of the aforementioned inflammatory factors and either NHL or MM concurrently, robustly controlled for additional obesity-related hormonal factors. Thus, despite the strong and consistent data appearing to link inflammatory cytokines with NHL, the extent to which the cytokine-NHL relationship might be explained by other correlated obesity-related hormonal factors remains unknown. 


\section{THE RELATIONSHIP OF INSULIN AND THE INSULIN-LIKE GROWTH FACTOR (IGF) AXIS WITH B-CELL LYMPHOMAS AND MM}

The relation of obesity, type 2 diabetes, and a sedentary lifestyle, with risk of several solid tumors, has led to the hypothesis that high insulin levels may increase risk of cancer $(7,8,41,59-62)$. In addition to its well-known metabolic activity, insulin is a growth factor for a wide range of tissues and in fact plays a significant role in normal organogenesis during fetal development. Insulin shares approximately $40 \%$ amino acid sequence homology with IGF-I, the primary mediator of the growth effects of growth hormone. Binding of insulin or IGF-I to their own receptors can promote cell proliferation by activation of the same two downstream pathways: the $\mathrm{p} 21 / \mathrm{ras} /$ mitogenactivated protein kinase and phosphatidyl inositol-3 kinase (PI-3K) signaling pathways. Consistent with this, genes that underlie the PI-3K/AKT pathway are often mutated in several forms of NHL and Hodgkin lymphoma, resulting in high tumor tissue levels of phosphorylated AKT (a major oncogenic effector of this pathway) (63-65), whereas RAS/RAF mutations are common in MM (66). Insulin may also increase bioactive IGF-I levels by lowering production or increasing proteolysis of certain IGF binding proteins (IGFBPs). However, levels of IGF-I are less consistently elevated in obese or diabetic patients than are insulin levels. Thus, it is insulin, and not IGF-I, that has generally been thought to play a major role in the relationship of obesity/diabetes with cancer (60). For example, strong positive associations between fasting insulin levels and postmenopausal breast cancer have been observed $(67,68)$ and found to largely explain the relationship of obesity with breast cancer (e.g., statistical adjustment for insulin but not sex hormones in multivariate models eliminated the relation of obesity with disease) $(67,69)$, whereas there are conflicting data regarding the association of circulating IGF-I and postmenopausal breast cancer $(67,70,71)$.

In animal models, insulin has independent mitogenic/ antiapoptotic activity, and overexpression of insulin receptors (IRs) can result in cell transformation and tumor cell proliferation in vitro (72). IRs are highly expressed in many human cancers (73-76), including NHL and MM cell lines (77). However, it is generally the IR-A isoform (which plays a major role in fetal development) that is disproportionately expressed in most tumors, and not the IR-B isoform (which plays a major role in metabolism) (78). As with their ligands, there is considerable homology between IRs and the IGF-I receptor (IGF-I), although binding of the alternative receptor does not meaningfully occur at physiologic levels. Nonetheless, both IR-A and IR-B can form hybrid receptors with IGF-IR, and these hybrids are reported to bind both insulin and IGFs (despite ongoing uncertainty regarding their relative affinities) (78). Laboratory data suggest that it is most likely the IR-A/IGF-IR hybrid receptor that plays the major role in insulin signaling and MM tumorigenesis (79). Less data of this type have been reported for NHL. However, there are limited human data regarding the relation of circulating insulin or IGF-I levels with NHL and MM. A prospective cohort study observed that females reporting adult-onset diabetes were at an increased risk of NHL if they used insulin (80), but to the best of our knowledge no studies have assessed endogenous insulin levels and NHL. One multicohort consortium study of MM risk and its relation with prediagnostic IGF-I, as well as IGFBPs 1 and 3 (IGFBP-1 and IGFBP-3), has been reported (81). In this study, C-peptide, a marker of insulin secretion, was used as a surrogate for insulin. Of the insulin/IGF axis proteins studied, only IGFBP-1 had a significant (positive) association with MM. However, a substantial portion of bloods tested were non-fasting samples, and recent data have shown that fasting versus postprandial levels of C-peptide differ to a similar degree as insulin levels, making non-fasting C-peptide results difficult to interpret (82).

Overall, we are unaware of any studies of the insulin/IGF axis and its role in NHL or MM development that have adequately addressed concerns regarding the use of non-fasting blood specimens, inclusion of type 2 diabetics (or pre-diabetics using diabetic medication) or inclusion of postmenopausal women using HT. Finally, there are two isoforms of the IR. While the IR-B isoform plays the primary role in metabolism, IR-A plays a major role in fetal development and organogenesis, and it is IR-A that has been most associated with cancer development in laboratory and clinical studies $(78,83)$. Several common cancers have been shown to overexpress IR-A $(78,84-86)$. To the best of our knowledge, however, no studies have examined the IR isoforms in relation to risk of NHL or MM.

\section{THE RELATIONSHIP OF SEX HORMONES WITH B-CELL LYMPHOMAS AND MM}

Obesity strongly influences several aspects of sex hormone biology. Obesity and high insulin levels are associated with lower levels of sex hormone binding globulin (SHBG) (87). Furthermore, obesity increases production of estrogen in postmenopausal women $(88,89)$ due to the activity of aromatase (estrogen synthetase) related biosynthesis of estrogens from lipids in adipose tissue $(90,91)$, and increases production of testosterone in men (92). As such, obesity-related reduced SHBG levels and increased production of estrogen and testosterone can lead to greater free/ bioactive estrogen and testosterone levels.

Laboratory models have shown that estrogen can promote the differentiation, proliferation, and survival of hematopoietic cells $(93,94)$, and more specifically the maturation, selection, and secretion of antibodies by B-cells (95). Briefly, B cells develop from hematopoietic stem cells (HSCs) that originate in the bone marrow (96). These early phase B-cells then migrate to the spleen where they undergo further development, becoming mature B-cells (97). The administration of estrogen to mice reduces the mitotic activity of Ref. (98) and the number of B-cell precursors in the bone marrow (99). Estrogen (either alone or in combination with progesterone) administered to both male and female mice without exceeding the physiological levels observed during pregnancy was shown to promote the self-renewal of HSCs, as well as mobilization of T1 B-cells to the spleen for additional development (100).

There is considerable biologic cross talk between sex hormone signaling and other obesity-related hormonal pathways associated 
with risk of NHL and MM (101). For example, (i) ER and IGF-IR expression are correlated (102-107), (ii) estrogen increases IGF-IR levels (108), (iii) IGF-I enhances ER responsiveness to estrogen (109), (iv) insulin decreases levels of SHBG (110), (v) insulin upregulates androgen secretion by the ovaries (110), and (vi) insulin increases ER expression and binding capacity (60). Recent evidence suggests that estradiol administration significantly increases single cytokine secretion, notably TNF $\alpha$ and IL4, and polyfunctionality of antigen-specific T cells (111).

Epidemiologic studies have also provided some support for a role for sex hormones in the etiology of NHL and MM. Increased gravidity and parity are thought to reduce lifetime exposure to estrogens and have been associated with reduced risk of NHL (112-116), as is the case for postmenopausal breast cancer (117). For example, the InterLymph study reported that high gravidity was associated with reduced risk of FL in 7 of the 13 case-control studies that were analyzed (118). Three of these studies also observed significantly reduced risk of NHL with increased parity (119-121), and/or for FL with gravidity (118). The prospective California Teachers Study observed a reduced risk of NHL associated with increasing number of pregnancies and full-term pregnancies (116), although not all cohort studies have found these associations $(112,115)$.

Commonly used oral HT in the US contains animal-derived estrogens, predominantly estrone, that has lower mitogenic activity than estradiol, and use of estrogen-alone HT has been associated with reduced risk of estrogen-driven cancers such as postmenopausal breast cancer (122). Consistent with this, DLBCL risk is reduced with use of oral estrogen-alone HT. While the number of cases of NHL and MM in the WHI clinical trial was too limited to analyze separately, a pooled analysis of 9 casecontrol studies (2,094 cases; 2,731 controls) observed that, compared with never users, postmenopausal women who had ever used HT (estrogen or estrogen/progesterone) were at decreased risk of DLBCL ( $\mathrm{OR}=0.66,95 \% \mathrm{CI}=0.54-0.80)$ and potentially $\mathrm{FL}(\mathrm{OR}=0.82,95 \% \mathrm{CI}=0.66-1.01)$ (123). A recent pooled analysis of case-control studies ( $n=7 ; \sim 1,000$ cases) in the IMMC evaluated reproductive factors and exogenous hormone use in relation to the risk of MM in women and observed protective, but non-significant, associations with parity and HT use (124).

Overall, these data support the largely unexplored hypothesis that the sex hormone axis may play a role in lymphoma and MM development, as well as also the importance of addressing the extensive cross talk and correlation between sex hormones and other obesity-related molecular risk factors for these cancers. To the best of our knowledge, however, there have been no studies of circulating endogenous sex hormones and risk of DLBCL, FL, CLL, or MM, in women or men.

\section{DESIGN CONSIDERATIONS FOR STUDIES OF OBESITY-RELATED HORMONES AND ADIPOCYTOKINES IN THE ETIOLOGY STUDIES OF CANCER}

The collective findings to date not only provide important initial evidence that specific obesity-related hormonal and cytokine alterations may influence the risk of B-cell hematologic malignancies but also help inform decisions regarding future clinical/ epidemiologic study design. Several research concerns particular to this area of investigation were briefly mentioned earlier and should be addressed:

- Fasting blood specimens should be used for measuring all factors that may vary postprandially, which include not only insulin but also C-peptide (a biomarker of insulin secretion). C-peptide has often been used as a surrogate for insulin when fasting specimens were unavailable, under the widespread assumption that $\mathrm{C}$-peptide values are less altered by time since the last meal. However, several recent studies have shown that insulin and C-peptide values vary to a similar extent postprandially (82). Likewise, IGFBP-1, free/bioactive IGF-I, SHBG, and possibly free/bioactive estrogen and testosterone, may vary postprandially and should all be measured using fasting blood specimens. Alternatively, time since last meal may be used to address these concerns, albeit, not as robust as using fasting samples.

- HT use and type 2 diabetes status should be taken into account in future studies. Oral estrogens exert a strong first pass effect on the liver that alters hepatic protein production and changes levels of multiple hormones as well as inflammatory cytokines. Similarly, exclusion of type 2 diabetics and prediabetics using diabetes medication may be important since use of these medications is largely intended to reduce/counteract insulin resistance and also affects other insulin/IGF axis proteins, and other metabolic hormones, thereby potentially severing the relation of obesity with the relevant molecular pathways involved in hematologic carcinogenesis. A precedent for this comes from a prior study of the relation of insulin with postmenopausal breast cancer in non-diabetic women, which showed that the association was much stronger following exclusion of HT users $(67,68)$. Regardless of whether HT use and type 2 diabetes are addressed in sensitivity analyses or through study design exclusion criteria (e.g., due to concerns regarding sample size), it is important to this field of research that these issues be addressed by all studies since it is a potential source of bias and of conflicting reports in the literature. In addition, the exclusion of individuals receiving testosterone treatment should be carefully considered.

- Assessment of inter-related biomarkers involves several considerations. First, sample size and power calculations must take these correlations into account, and if multiple comparisons are a concern then the $P$-value required for statistical significance may need to be reduced (e.g., using the BenjaminiHochberg procedure) and false discovery rates should be evaluated. There may also be concerns regarding collinearity. However, collinearity is usually only relevant for very strong correlations (e.g., $r>0.8$ ), and most of the hormones and cytokines discussed earlier have only moderate correlations. For example, among the strongest correlations is that between IGF-I and IGFBP-3, in the range of $r=0.3-0.5$ (67). Additional analytical approaches, such as Mendelian randomization (125), may also help elucidate the roles of specific biomarkers. Finally, given how the insulin/IGF-1, inflammatory, and sex 
hormone pathways interrelate/cross talk, mediation analyses should be considered to further elaborate these associations. For example, counterfactual-based mediation analyses (126) can be carried out to refine the decomposition of the effects of sex hormones, inflammation, and insulin into the mediated effects versus the remaining direct effects.

- Studies of hematologic malignancies also require additional, special consideration. Given the heterogeneity of disease subtypes, and associated etiological factors, studies must be designed to include sufficient number of cases for any particular subtype to ensure that subtype-specific analyses have $>80 \%$ power. Given the rarity of NHL and MM, pooled nested case-control studies leveraging prediagnostic samples would be most likely needed.

\section{CONCLUSION}

Obesity is now an established risk factor for DLBCL and MM, and possibly additional B-cell lymphoma subtypes. Growing evidence suggests that several obesity-related molecular factors and downstream signaling pathways that have been increasingly shown to play a role in carcinogenesis of several common solid tumors may also play a role in NHL and MM. These risk factors include inflammatory factors, particularly IL10 and TNF $\alpha$, as well as sCD27 and sCD30; metabolic factors, particularly insulin and the IGF axis; and endogenous sex hormones, particularly estrogen. To date, however, these associations have not been concurrently evaluated in robust study designs (i.e., prospective cohorts with sufficient follow-up), which are needed to determine the likely underlying etiologic mechanisms, especially given the correlation among many of the obesity-related circulating factors. Stronger and more consistent associations with cancer risk would be expected if the obesity-related downstream molecular pathways underlying

\section{REFERENCES}

1. Jemal A, Bray F, Center MM, Ferlay J, Ward E, Forman D. Global cancer statistics. CA Cancer J Clin (2011) 61(2):69-90. doi:10.3322/caac.20107

2. Wang SS, Slager SL, Brennan P, Holly EA, de SS, Bernstein L, et al. Family history of hematopoietic malignancies and risk of non-Hodgkin lymphoma (NHL): a pooled analysis of 10211 cases and 11905 controls from the International Lymphoma Epidemiology Consortium (InterLymph). Blood (2007) 109(8):3479-88. doi:10.1182/blood-2006-06-031948

3. Muller AM, Ihorst G, Mertelsmann R, Engelhardt M. Epidemiology of non-Hodgkin's lymphoma (NHL): trends, geographic distribution, and etiology. Ann Hematol (2005) 84(1):1-12. doi:10.1007/s00277-0040939-7

4. Schottenfeld D, Fraumeni JF. Cancer Epidemiology and Prevention. 3rd ed. Oxford, New York: Oxford University Press (2006). xviii, 1392 p.

5. Jemal A, Siegel R, Xu J, Ward E. Cancer statistics, 2010. CA Cancer J Clin (2010) 60(5):277-300. doi:10.3322/caac.20073

6. Larsson SC, Wolk A. Body mass index and risk of non-Hodgkin's and Hodgkin's lymphoma: a meta-analysis of prospective studies. Eur J Cancer (2011) 47(16):2422-30. doi:10.1016/j.ejca.2011.06.029

7. Renehan AG, Tyson M, Egger M, Heller RF, Zwahlen M. Body-mass index and incidence of cancer: a systematic review and meta-analysis of prospective observational studies. Lancet (2008) 371(9612):569-78. doi:10.1016/ s0140-6736(08)60269-x obesity's relation with MM and B-cell NHL are directly assessed as exposure variables rather than adiposity itself. Obesity is highly prevalent in the US and many other countries around the world. Understanding the molecular pathways which underlie the relation of obesity with NHL and MM is key to identifying biomarkers for risk stratification, as well as new biologic targets for chemoprevention or treatment, particularly given the increasing incidence of hematological malignancies in countries experiencing obesity epidemics (127).

\section{KEY MESSAGES}

- Obesity has been associated with risk of B-cell non-Hodgkin lymphomas (NHLs) and multiple myeloma (MM).

- The underlying mechanisms for obesity-related hematopoiesis may include inflammatory cytokines, hyperinsulinemia, and sex hormones; however, evidence is either limited or has been conflicting.

- The current literature is challenged by studies not robustly accounting for hormone therapy use and type 2 diabetes status, as well as having limited power for NHL subtype-specific analyses.

- All potential associations need to be concurrently evaluated in robust study designs (i.e., large-scale prospective cohorts with sufficient follow-up time and prediagnostic fasting blood samples) to determine the likely underlying etiologic mechanisms, especially given the correlation among many of the obesity-related circulating factors.

\section{AUTHOR CONTRIBUTIONS}

$\mathrm{HH}, \mathrm{MG}, \mathrm{NM}$, TR, and HS were responsible for critically evaluating the content of the manuscript and providing approval for the final version to be published.

8. Renehan AG, Zwahlen M, Egger M. Adiposity and cancer risk: new mechanistic insights from epidemiology. Nat Rev Cancer (2015) 15(8):484-98. doi:10.1038/nrc3967

9. Lauby-Secretan B, Scoccianti C, Loomis D, Grosse Y, Bianchini F, Straif K. Body fatness and cancer - VIEWPOINT of the IARC Working Group. N Engl J Med (2016) 375(8):794-8. doi:10.1056/NEJMsr1606602

10. Aleksandrova K, Stelmach-Mardas M, Schlesinger S. Obesity and liver cancer. Recent Results Cancer Res (2016) 208:177-98. doi:10.1007/978-3-31942542-9_10

11. Cao Y, Giovannucci E. Obesity and prostate cancer. Recent Results Cancer Res (2016) 208:137-53. doi:10.1007/978-3-319-42542-9_8

12. Fortner RT, Katzke V, Kuhn T, Kaaks R. Obesity and breast cancer. Recent Results Cancer Res (2016) 208:43-65. doi:10.1007/978-3-319-42542-9_3

13. Jochem C, Leitzmann M. Obesity and colorectal cancer. Recent Results Cancer Res (2016) 208:17-41. doi:10.1007/978-3-319-42542-9_2

14. Nimptsch K, Steffen A, Pischon T. Obesity and oesophageal cancer. Recent Results Cancer Res (2016) 208:67-80. doi:10.1007/978-3-319-42542-9_4

15. Pischon T, Nimptsch K. Obesity and risk of cancer: an introductory overview. Recent Results Cancer Res (2016) 208:1-15.doi:10.1007/978-3-319-42542-9_1

16. Shaw E, Farris M, McNeil J, Friedenreich C. Obesity and endometrial cancer. Recent Results Cancer Res (2016) 208:107-36. doi:10.1007/978 3-319-42542-9_7

17. Tworoger SS, Huang T. Obesity and ovarian cancer. Recent Results Cancer Res (2016) 208:155-76. doi:10.1007/978-3-319-42542-9_9 
18. Wilson KM, Cho E. Obesity and kidney cancer. Recent Results Cancer Res (2016) 208:81-93. doi:10.1007/978-3-319-42542-9_5

19. Lim U, Morton LM, Subar AF, Baris D, Stolzenberg-Solomon R, Leitzmann M, et al. Alcohol, smoking, and body size in relation to incident Hodgkin's and non-Hodgkin's lymphoma risk. Am J Epidemiol (2007) 166(6):697-708. doi:10.1093/aje/kwm122

20. Bertrand KA, Giovannucci E, Zhang SM, Laden F, Rosner B, Birmann BM. A prospective analysis of body size during childhood, adolescence, and adulthood and risk of non-Hodgkin lymphoma. Cancer Prev Res (Phila) (2013) 6(8):864-73. doi:10.1158/1940-6207.capr-13-0132

21. Kabat GC, Kim MY, Jean Wactawski W, Bea JW, Edlefsen KL, AdamsCampbell LL, et al. Anthropometric factors, physical activity, and risk of non-Hodgkin's lymphoma in the Women's Health Initiative. Cancer Epidemiol (2012) 36(1):52-9. doi:10.1016/j.canep.2011.05.014

22. Leiba M, Leiba A, Keinan-Boker L, Avigdor A, Derazne E, Levine H, et al. Adolescent weight and height are predictors of specific non-Hodgkin lymphoma subtypes among a cohort of 2,352,988 individuals aged 16 to 19 years. Cancer (2016) 122(7):1068-77. doi:10.1002/cncr.29792

23. Patel AV, Diver WR, Teras LR, Birmann BM, Gapstur SM. Body mass index, height and risk of lymphoid neoplasms in a large United States cohort. Leuk Lymphoma (2013) 54(6):1221-7. doi:10.3109/10428194.2012.742523

24. Britton JA, Khan AE, Rohrmann S, Becker N, Linseisen J, Nieters A, et al. Anthropometric characteristics and non-Hodgkin's lymphoma and multiple myeloma risk in the European Prospective Investigation into Cancer and Nutrition (EPIC). Haematologica (2008) 93(11):1666-77. doi:10.3324/ haematol.13078

25. Cerhan JR, Janney CA, Vachon CM, Habermann TM, Kay NE, Potter JD. Anthropometric characteristics, physical activity and risk of non-Hodgkin's Lymphoma subtypes and B-cell chronic lympocytic leukemia: a prospective study. Am J Epidemiol (2002) 156:527-35. doi:10.1093/aje/kwf082

26. Soderberg KC, Kaprio J, Verkasalo PK, Pukkala E, Koskenvuo M, Lundqvist E, et al. Overweight, obesity and risk of haematological malignancies: a cohort study of Swedish and Finnish twins. Eur J Cancer (2009) 45(7):1232-8. doi:10.1016/j.ejca.2008.11.004

27. Reeves GK, Pirie K, Beral V, Green J, Spencer E, Bull D, et al. Cancer incidence and mortality in relation to body mass index in the Million Women Study: cohort study. BMJ (2007) 335(7630):1134. doi:10.1136/bmj.39367. 495995.AE

28. MacInnis RJ, English DR, Hopper JL, Giles GG. Body size and composition and the risk of lymphohematopoietic malignancies. J Natl Cancer Inst (2005) 97(15):1154-7. doi:10.1093/jnci/dji209

29. Rapp K, Schroeder J, Klenk J, Stoehr S, Ulmer H, Concin H, et al. Obesity and incidence of cancer: a large cohort study of over 145,000 adults in Austria. Br J Cancer (2005) 93(9):1062-7. doi:10.1038/sj.bjc.6602819

30. Kanda J, Matsuo K, Inoue M, Iwasaki M, Sawada N, Shimazu T, et al. Association of anthropometric characteristics with the risk of malignant lymphoma and plasma cell myeloma in a Japanese population: a population-based cohort study. Cancer Epidemiol Biomarkers Prev (2010) 19(6):1623-31. doi:10.1158/1055-9965.epi-10-0171

31. Oh SW, Yoon YS, Shin SA. Effects of excess weight on cancer incidences depending on cancer sites and histologic findings among men: Korea National Health Insurance Corporation Study. J Clin Oncol (2005) 23(21):4742-54. doi:10.1200/jco.2005.11.726

32. Engeland A, Tretli S, Hansen S, Bjorge T. Height and body mass index and risk of lymphohematopoietic malignancies in two million Norwegian men and women. Am J Epidemiol (2007) 165(1):44-52. doi:10.1093/aje/kwj353

33. Lukanova A, Bjor O, Kaaks R, Lenner P, Lindahl B, Hallmans G, et al. Body mass index and cancer: results from the Northern Sweden Health and Disease Cohort. Int J Cancer (2006) 118(2):458-66. doi:10.1002/ijc.21354

34. Samanic C, Chow WH, Gridley G, Jarvholm B, Fraumeni JF Jr. Relation of body mass index to cancer risk in 362,552 Swedish men. Cancer Causes Control (2006) 17(7):901-9. doi:10.1007/s10552-006-0023-9

35. Pylypchuk RD, Schouten LJ, Goldbohm RA, Schouten HC, van den Brandt PA. Body mass index, height, and risk of lymphatic malignancies: a prospective cohort study. Am JEpidemiol (2009) 170(3):297-307. doi:10.1093/aje/ kwp123

36. Zhang S, Hunter DJ, Rosner BA, Colditz GA, Fuchs CS, Speizer FE, et al. Dietary fat and protein in relation to risk of non-Hodgkin's lymphoma among women. J Natl Cancer Inst (1999) 91(20):1751-8. doi:10.1093/jnci/91.20.1751
37. Troy JD, Hartge P, Weissfeld JL, Oken MM, Colditz GA, Mechanic LE, et al. Associations between anthropometry, cigarette smoking, alcohol consumption, and non-Hodgkin lymphoma in the Prostate, Lung, Colorectal, and Ovarian Cancer Screening Trial. Am J Epidemiol (2010) 171(12):1270-81. doi:10.1093/aje/kwq085

38. Lu Y, Prescott J, Sullivan-Halley J, Henderson KD, Ma H, Chang ET, et al. Body size, recreational physical activity, and B-cell non-Hodgkin lymphoma risk among women in the California teachers study. Am J Epidemiol (2009) 170(10):1231-40. doi:10.1093/aje/kwp268

39. Wallin A, Larsson SC. Body mass index and risk of multiple myeloma: a meta-analysis of prospective studies. Eur J Cancer (2011) 47(11):1606-15. doi:10.1016/j.ejca.2011.01.020

40. Hofmann JN, Moore SC, Lim U, Park Y, Baris D, Hollenbeck AR, et al. Body mass index and physical activity at different ages and risk of multiple myeloma in the NIH-AARP diet and health study. Am J Epidemiol (2013) 177(8):776-86. doi:10.1093/aje/kws295

41. Birmann BM, Andreotti G, De Roos AJ, Camp NJ, Chiu BCH, Spinelli JJ, et al. Young adult and usual adult body mass index and multiple myeloma risk: a pooled analysis in the International Multiple Myeloma Consortium (IMMC). Cancer Epidemiol Biomarkers Prev (2017) 26(6):876-85. doi:10.1158/1055-9965.epi-16-0762-t

42. Bazzoni F, Beutler B. The tumor necrosis factor ligand and receptor families. N Engl J Med (1996) 334(26):1717-25. doi:10.1056/nejm199606273342607

43. Friederichs K, Schmitz J, Weissenbach M, Heinrich PC, Schaper F. Interleukin6-induced proliferation of pre-B cells mediated by receptor complexes lacking the SHP2/SOCS3 recruitment sites revisited. Eur J Biochem (2001) 268(24):6401-7. doi:10.1046/j.0014-2956.2001.02586.x

44. Auphan N, DiDonato JA, Rosette C, Helmberg A, Karin M. Immunosuppression by glucocorticoids: inhibition of NF-kappa B activity through induction of I kappa B synthesis. Science (1995) 270(5234):286-90. doi:10.1126/ science. 270.5234 .286

45. Pikarsky E, Porat RM, Stein I, Abramovitch R, Amit S, Kasem S, et al. NF-kappaB functions as a tumour promoter in inflammation-associated cancer. Nature (2004) 431(7007):461-6. doi:10.1038/nature02924

46. Bailey DP, Kashyap M, Bouton LA, Murray PJ, Ryan JJ. Interleukin-10 induces apoptosis in developing mast cells and macrophages. J Leukoc Biol (2006) 80(3):581-9. doi:10.1189/jlb.0405201

47. Pellegrini P, Berghella AM, Contasta I, Adorno D. CD30 antigen: not a physiological marker for TH2 cells but an important costimulator molecule in the regulation of the balance between TH1/TH2 response. Transpl Immunol (2003) 12(1):49-61. doi:10.1016/s0966-3274(03)00014-5

48. De Milito A, Aleman S, Marenzi R, Sonnerborg A, Fuchs D, Zazzi M, et al. Plasma levels of soluble CD27: a simple marker to monitor immune activation during potent antiretroviral therapy in HIV-1-infected subjects. Clin Exp Immunol (2002) 127(3):486-94. doi:10.1046/j.1365-2249. 2002.01786.x

49. Cordingley FT, Bianchi A, Hoffbrand AV, Reittie JE, Heslop HE, Vyakarnam A, et al. Tumour necrosis factor as an autocrine tumour growth factor for chronic B-cell malignancies. Lancet (1988) 1(8592):969-71. doi:10.1016/ S0140-6736(88)91782-5

50. De Roos AJ, Mirick DK, Edlefsen KL, LaCroix AZ, Kopecky KJ, Madeleine MM, et al. Markers of B-cell activation in relation to risk of non-Hodgkin lymphoma. Cancer Res (2012) 72(18):4733-43. doi:10.1158/0008-5472.can12-1639

51. Edlefsen KL, Martinez-Maza O, Madeleine MM, Magpantay L, Mirick DK, Kopecky KJ, et al. Cytokines in serum in relation to future non-Hodgkin lymphoma risk: evidence for associations by histologic subtype. Int $J$ Cancer (2014) 135(4):913-22. doi:10.1002/ijc.28724

52. Purdue MP, Lan Q, Bagni R, Hocking WG, Baris D, Reding DJ, et al. Prediagnostic serum levels of cytokines and other immune markers and risk of non-Hodgkin lymphoma. Cancer Res (2011) 71(14):4898-907. doi:10.1158/0008-5472.can-11-0165

53. Purdue MP, Hofmann JN, Kemp TJ, Chaturvedi AK, Lan Q, Park JH, et al. A prospective study of 67 serum immune and inflammation markers and risk of non-Hodgkin lymphoma. Blood (2013) 122(6):951-7. doi:10.1182/ blood-2013-01-481077

54. Saberi Hosnijeh F, Krop EJ, Scoccianti C, Krogh V, Palli D, Panico S, et al. Plasma cytokines and future risk of non-Hodgkin lymphoma (NHL): a case-control study nested in the Italian European Prospective Investigation 
into Cancer and Nutrition. Cancer Epidemiol Biomarkers Prev (2010) 19(6):1577-84. doi:10.1158/1055-9965.epi-09-1237

55. Conroy SM, Maskarinec G, Morimoto Y, Franke AA, Cooney RV, Wilkens LR, et al. Non-Hodgkin lymphoma and circulating markers of inflammation and adiposity in a nested case-control study: the multiethnic cohort. Cancer Epidemiol Biomarkers Prev (2013) 22(3):337-47. doi:10.1158/1055-9965. epi-12-0947

56. Purdue MP, Lan Q, Kemp TJ, Hildesheim A, Weinstein SJ, Hofmann JN, et al. Elevated serum sCD23 and sCD30 up to two decades prior to diagnosis associated with increased risk of non-Hodgkin lymphoma. Leukemia (2015) 29(6):1429-31. doi:10.1038/leu.2015.2

57. Hofmann JN, Birmann BM, Teras LR, Pfeiffer RM, Wang Y, Albanes D, et al. Low levels of circulating adiponectin are associated with multiple myeloma risk in overweight and obese individuals. Cancer Res (2016) 76(7):1935-41. doi:10.1158/0008-5472.can-15-2406

58. Hofmann JN, Liao LM, Pollak MN, Wang Y, Pfeiffer RM, Baris D, et al. A prospective study of circulating adipokine levels and risk of multiple myeloma. Blood (2012) 120(22):4418-20. doi:10.1182/blood-2012-06-438606

59. Colditz GA, Peterson LL. Obesity and cancer: evidence, impact, and future directions. Clin Chem (2018) 64(1):154-62. doi:10.1373/clinchem. 2017.277376

60. Strickler HD, Wylie-Rosett J, Rohan T, Hoover DR, Smoller S, Burk RD, et al. The relation of type 2 diabetes and cancer. Diabetes Technol Ther (2001) 3(2):263-74. doi:10.1089/152091501300209633

61. Anderson AS, Key TJ, Norat T, Scoccianti C, Cecchini M, Berrino F, et al. European code against cancer 4th edition: obesity, body fatness and cancer. Cancer Epidemiol (2015) 39(Suppl 1):S34-45. doi:10.1016/j.canep. 2015.01.017

62. Giovannucci E. Insulin and colon cancer. Cancer Causes Control (1995) 6(2):164-79. doi:10.1007/BF00052777

63. Westin JR. Status of PI3K/Akt/mTOR pathway inhibitors in lymphoma. Clin Lymphoma Myeloma Leuk (2014) 14(5):335-42. doi:10.1016/j.clml. 2014.01.007

64. Pfeifer M, Grau M, Lenze D, Wenzel SS, Wolf A, Wollert-Wulf B, et al. PTEN loss defines a PI3K/AKT pathway-dependent germinal center subtype of diffuse large B-cell lymphoma. Proc Natl Acad Sci U S A (2013) 110(30): 12420-5. doi:10.1073/pnas.1305656110

65. Argyriou P, Economopoulou P, Papageorgiou S. The role of mTOR inhibitors for the treatment of B-cell lymphomas. Adv Hematol (2012) 2012:435342. doi:10.1155/2012/435342

66. Xu J, Pfarr N, Endris V, Mai EK, Md Hanafiah NH, Lehners N, et al. Molecular signaling in multiple myeloma: association of RAS/RAF mutations and MEK/ERK pathway activation. Oncogenesis (2017) 6(5):e337. doi:10.1038/ oncsis. 2017.36

67. Gunter MJ, Hoover DR, Yu H, Wassertheil-Smoller S, Rohan TE, Manson JE, et al. Insulin, insulin-like growth factor-I, and risk of breast cancer in postmenopausal women. J Natl Cancer Inst (2009) 101(1):48-60. doi:10.1093/ jnci/djn415

68. Gunter MJ, Xie X, Xue X, Kabat GC, Rohan TE, Wassertheil-Smoller S, et al. Breast cancer risk in metabolically healthy but overweight postmenopausal women. Cancer Res (2015) 75(2):270-4. doi:10.1158/0008-5472. can-14-2317

69. Hvidtfeldt UA, Gunter MJ, Lange T, Chlebowski RT, Lane DS, Farhat GN, et al. Quantifying mediating effects of endogenous estrogen and insulin in the relation between obesity, alcohol consumption and breast cancer. Cancer Epidemiol Biomarkers Prev (2012) 21(7):1203-12. doi:10.1158/1055-9965. epi-12-0310

70. Schairer C, McCarty CA, Isaacs C, Sue LY, Pollak MN, Berg CD, et al. Circulating insulin-like growth factor (IGF)-I and IGF binding protein (IGFBP)-3 levels and postmenopausal breast cancer risk in the prostate, lung, colorectal, and ovarian cancer screening trial (PLCO) cohort. Horm Cancer (2010) 1(2):100-11. doi:10.1007/s12672-010-0013-y

71. Endogenous Hormones and Breast Cancer Collaborative Group, Key TJ, Appleby PN, Reeves GK, Roddam AW. Insulin-like growth factor 1 (IGF1), IGF binding protein 3 (IGFBP3), and breast cancer risk: pooled individual data analysis of 17 prospective studies. Lancet Oncol (2010) 11(6):530-42. doi:10.1016/s1470-2045(10)70095-4

72. Giorgino F, Belfiore A, Milazzo G, Costantino A, Maddux B, Whittaker J, et al. Overexpression of insulin receptors in fibroblast and ovary cells induces a ligand-mediated transformed phenotype. Mol Endocrinol (1991) 5(3): 452-9. doi:10.1210/mend-5-3-452

73. Kim YI. Diet, lifestyle, and colorectal cancer: is hyperinsulinemia the missing link? Nutr Rev (1998) 56(9):275-9. doi:10.1111/j.1753-4887.1998.tb01765.x

74. Fisher WE, Boros LG, Schirmer WJ. Insulin promotes pancreatic cancer: evidence for endocrine influence on exocrine pancreatic tumors. J Surg Res (1996) 63(1):310-3. doi:10.1006/jsre.1996.0266

75. Fisher WE, Boros LG, O’Dorisio TM, O’Dorisio MS, Schirmer WJ. GI hormonal changes in diabetes influence pancreatic cancer growth. J Surg Res (1995) 58(6):754-8. doi:10.1006/jsre.1995.1119

76. Papa V, Pezzino V, Costantino A, Belfiore A, Giuffrida D, Frittitta L, et al. Elevated insulin receptor content in human breast cancer. J Clin Invest (1990) 86(5):1503-10. doi:10.1172/jci114868

77. Freund GG, Kulas DT, Way BA, Mooney RA. Functional insulin and insulin-like growth factor-1 receptors are preferentially expressed in multiple myeloma cell lines as compared to B-lymphoblastoid cell lines. Cancer Res (1994) 54(12):3179-85.

78. Belfiore A, Malaguarnera R, Vella V, Lawrence MC, Sciacca L, Frasca F, et al. Insulin receptor isoforms in physiology and disease: an updated view. Endocr Rev (2017) 38(5):379-431. doi:10.1210/er.2017-00073

79. Sprynski AC, Hose D, Kassambara A, Vincent L, Jourdan M, Rossi JF, et al. Insulin is a potent myeloma cell growth factor through insulin/IGF-1 hybrid receptor activation. Leukemia (2010) 24(11):1940-50. doi:10.1038/ leu.2010.192

80. Cerhan JR, Wallace RB, Lutz CT, Folsom AR, Thomas AS, Zheng W, et al. Medical history risk factors for non-Hodgkin's lymphoma in older women. J Natl Cancer Inst (1997) 89(4):314-8. doi:10.1093/jnci/89.4.314

81. Birmann BM, Neuhouser ML, Rosner B, Albanes D, Buring JE, Giles GG, et al. Prediagnosis biomarkers of insulin-like growth factor-1, insulin, and interleukin-6 dysregulation and multiple myeloma risk in the Multiple Myeloma Cohort Consortium. Blood (2012) 120(25):4929-37. doi:10.1182/ blood-2012-03-417253

82. Murphy N, Falk RT, Messinger DB, Pollak M, Xue X, Lin J, et al. Influence of fasting status and sample preparation on metabolic biomarker measurements in postmenopausal women. PLoS One (2016) 11(12):e0167832. doi:10.1371/ journal.pone. 0167832

83. Denley A, Wallace JC, Cosgrove LJ, Forbes BE. The insulin receptor isoform exon 11- (IR-A) in cancer and other diseases: a review. Horm Metab Res (2003) 35(11-12):778-85. doi:10.1055/s-2004-814157

84. Perks CM, Zielinska HA, Wang J, Jarrett C, Frankow A, Ladomery MR, et al. Insulin receptor isoform variations in prostate cancer cells. Front Endocrinol (2016) 7:132. doi:10.3389/fendo.2016.00132

85. Flannery CA, Saleh FL, Choe GH, Selen DJ, Kodaman PH, Kliman HJ, et al. Differential expression of IR-A, IR-B and IGF-1R in endometrial physiology and distinct signature in adenocarcinoma. JClin Endocrinol Metab (2016) 101(7):2883-91. doi:10.1210/jc.2016-1795

86. Aljada A, Saleh AM, Al-Aqeel SM, Shamsa HB, Al-Bawab A, Al Dubayee M, et al. Quantification of insulin receptor mRNA splice variants as a diagnostic tumor marker in breast cancer. Cancer Biomark (2015) 15(5):653-61. doi:10.3233/cbm-150505

87. Karim R, Mack WJ, Hodis HN, Roy S, Stanczyk FZ. Influence of age and obesity on serum estradiol, estrone, and sex hormone binding globulin concentrations following oral estrogen administration in postmenopausal women. JClin Endocrinol Metab (2009) 94(11):4136-43. doi:10.1210/ jc.2009-0643

88. Simpson ER. Sources of estrogen and their importance. J Steroid Biochem Mol Biol (2003) 86(3-5):225-30. doi:10.1016/S0960-0760(03)00360-1

89. Nelson LR, Bulun SE. Estrogen production and action. J Am Acad Dermatol (2001) 45(3 Suppl):S116-24. doi:10.1067/mjd.2001.117432

90. Goodwin PJ. Obesity and endocrine therapy: host factors and breast cancer outcome. Breast (2013) 22(Suppl 2):S44-7. doi:10.1016/j.breast.2013.07.008

91. Morris PG, Hudis CA, Giri D, Morrow M, Falcone DJ, Zhou XK, et al. Inflammation and increased aromatase expression occur in the breast tissue of obese women with breast cancer. Cancer Prev Res (Phila) (2011) 4(7):1021-9. doi:10.1158/1940-6207.capr-11-0110

92. Pasquali R, Casimirri F, De Iasio R, Mesini P, Boschi S, Chierici R, et al. Insulin regulates testosterone and sex hormone-binding globulin concentrations in adult normal weight and obese men. J Clin Endocrinol Metab (1995) 80(2):654-8. doi:10.1210/jcem.80.2.7852532 
93. Fish EN. The X-files in immunity: sex-based differences predispose immune responses. Nat Rev Immunol (2008) 8(9):737-44. doi:10.1038/nri2394

94. Gourdy P, Araujo LM, Zhu R, Garmy-Susini B, Diem S, Laurell H, et al. Relevance of sexual dimorphism to regulatory $\mathrm{T}$ cells: estradiol promotes IFN-gamma production by invariant natural killer T cells. Blood (2005) 105(6):2415-20. doi:10.1182/blood-2004-07-2819

95. Peeva E, Zouali M. Spotlight on the role of hormonal factors in the emergence of autoreactive B-lymphocytes. Immunol Lett (2005) 101(2):123-43. doi:10.1016/j.imlet.2005.05.014

96. Hardy RR, Carmack CE, Shinton SA, Kemp JD, Hayakawa K. Resolution and characterization of pro-B and pre-pro-B cell stages in normal mouse bone marrow. JExp Med (1991) 173(5):1213-25. doi:10.1084/jem.173. 5.1213

97. Allman D, Lindsley RC, DeMuth W, Rudd K, Shinton SA, Hardy RR. Resolution of three nonproliferative immature splenic B cell subsets reveals multiple selection points during peripheral B cell maturation. J Immunol (2001) 167(12):6834-40. doi:10.4049/jimmunol.167.12.6834

98. Medina KL, Strasser A, Kincade PW. Estrogen influences the differentiation, proliferation, and survival of early B-lineage precursors. Blood (2000) 95(6):2059-67.

99. Smithson G, Beamer WG, Shultz KL, Christianson SW, Shultz LD, Kincade PW. Increased B lymphopoiesis in genetically sex steroid-deficient hypogonadal (hpg) mice. J Exp Med (1994) 180(2):717-20. doi:10.1084/ jem.180.2.717

100. Nakada D, Oguro H, Levi BP, Ryan N, Kitano A, Saitoh Y, et al. Oestrogen increases haematopoietic stem-cell self-renewal in females and during pregnancy. Nature (2014) 505(7484):555-8. doi:10.1038/nature 12932

101. Rachon D, Mysliwska J, Suchecka-Rachon K, Wieckiewicz J, Mysliwski A. Effects of oestrogen deprivation on interleukin- 6 production by peripheral blood mononuclear cells of postmenopausal women. J Endocrinol (2002) 172(2):387-95. doi:10.1677/joe.0.1720387

102. Peyrat JP, Bonneterre J, Beuscart R, Djiane J, Demaille A. Insulin-like growth factor 1 receptors in human breast cancer and their relation to estradiol and progesterone receptors. Cancer Res (1988) 48(22):6429-33.

103. Peyrat JP, Bonneterre J, Laurent JC, Louchez MM, Amrani S, Leroy-Martin B, et al. Presence and characterization of insulin-like growth factor 1 receptors in human benign breast disease. Eur J Cancer Clin Oncol (1988) 24(9):1425-31. doi:10.1016/0277-5379(88)90332-X

104. Peyrat JP, Bonneterre J. Type 1 IGF receptor in human breast diseases. Breast Cancer Res Treat (1992) 22(1):59-67. doi:10.1007/BF01833334

105. Peyrat JP, Bonneterre J, Hecquet B, Vennin P, Louchez MM, Fournier C, et al. Plasma insulin-like growth factor-1 (IGF-1) concentrations in human breast cancer. Eur J Cancer (1993) 29a(4):492-7. doi:10.1016/S0959-8049 (05)80137-6

106. Pekonen F, Partanen S, Makinen T, Rutanen EM. Receptors for epidermal growth factor and insulin-like growth factor I and their relation to steroid receptors in human breast cancer. Cancer Res (1988) 48(5):1343-7.

107. Papa V, Gliozzo B, Clark GM, McGuire WL, Moore D, Fujita-Yamaguchi Y, et al. Insulin-like growth factor-I receptors are overexpressed and predict a low risk in human breast cancer. Cancer Res (1993) 53(16):3736-40.

108. Yu H, Shu XO, Li BD, Dai Q, Gao YT, Jin F, et al. Joint effect of insulin-like growth factors and sex steroids on breast cancer risk. Cancer Epidemiol Biomarkers Prev (2003) 12(10):1067-73.

109. Ellis MJ, Jenkins S, Hanfelt J, Redington ME, Taylor M, Leek R, et al. Insulinlike growth factors in human breast cancer. Breast Cancer Res Treat (1998) 52(1-3):175-84. doi:10.1023/A:1006127621512

110. Lawlor DA, Smith GD, Ebrahim S. Hyperinsulinaemia and increased risk of breast cancer: findings from the British Women's Heart and Health Study. Cancer Causes Control (2004) 15(3):267-75. doi:10.1023/B:CACO. 0000024225.14618.a8

111. Navarro FC, Watkins SK. Estrogen stimulation differentially impacts human male and female antigen-specific T cell anti-tumor function and polyfunctionality. Gender Genome (2017) 1(4):167-79. doi:10.1089/gg.2017.0014

112. Morton LM, Wang SS, Richesson DA, Schatzkin A, Hollenbeck AR, Lacey JV Jr. Reproductive factors, exogenous hormone use and risk of lymphoid neoplasms among women in the National Institutes of Health-AARP Diet and Health Study Cohort. Int J Cancer (2009) 124(11):2737-43. doi:10.1002/ ijc. 24248
113. Teras LR, Patel AV, Hildebrand JS, Gapstur SM. Postmenopausal unopposed estrogen and estrogen plus progestin use and risk of non-Hodgkin lymphoma in the American Cancer Society Cancer Prevention Study-II Cohort. Leuk Lymphoma (2013) 54(4):720-5. doi:10.3109/10428194.2012.722216

114. Costas L, de Sanjose S, Infante-Rivard C. Reproductive factors and non-Hodgkin lymphoma: a systematic review. Crit Rev Oncol Hematol (2014) 92(3):181-93. doi:10.1016/j.critrevonc.2014.07.004

115. Cerhan JR, Habermann TM, Vachon CM, Putnam SD, Zheng W, Potter JD, et al. Menstrual and reproductive factors and risk of non-Hodgkin lymphoma: the Iowa women's health study (United States). Cancer Causes Control (2002) 13(2):131-6. doi:10.1023/A:1014354105164

116. Prescott J, Lu Y, Chang ET, Sullivan-Halley J, Henderson KD, Clarke CA, et al. Reproductive factors and non-Hodgkin lymphoma risk in the California Teachers Study. PLoS One (2009) 4(12):e8135. doi:10.1371/journal.pone.0008135

117. Brouckaert O, Rudolph A, Laenen A, Keeman R, Bolla MK, Wang Q, et al. Reproductive profiles and risk of breast cancer subtypes: a multicenter case-only study. Breast Cancer Res (2017) 19(1):119. doi:10.1186/ s13058-017-0909-3

118. Kane EV, Roman E, Becker N, Bernstein L, Boffetta P, Bracci PM, et al. Menstrual and reproductive factors, and hormonal contraception use: associations with non-Hodgkin lymphoma in a pooled analysis of InterLymph case-control studies. Ann Oncol (2012) 23(9):2362-74. doi:10.1093/annonc/ mds171

119. Zhang Y, Holford TR, Leaderer B, Boyle P, Zahm SH, Zhang B, et al. Menstrual and reproductive factors and risk of non-Hodgkin's lymphoma among Connecticut women. Am J Epidemiol (2004) 160(8):766-73. doi:10.1093/ aje/kwh278

120. Costas L, Casabonne D, Benavente Y, Becker N, Boffetta P, Brennan P, et al. Reproductive factors and lymphoid neoplasms in Europe: findings from the EpiLymph case-control study. Cancer Causes Control (2012) 23(1):195-206. doi:10.1007/s10552-011-9869-6

121. Lee JS, Bracci PM, Holly EA. Non-Hodgkin lymphoma in women: reproductive factors and exogenous hormone use. Am J Epidemiol (2008) 168(3):278-88. doi:10.1093/aje/kwn119

122. Chlebowski RT, Anderson GL. Menopausal hormone therapy and breast cancer mortality: clinical implications. Ther Adv Drug Saf (2015) 6(2):45-56. doi: 10.1177/2042098614568300

123. Kane EV, Bernstein L, Bracci PM, Cerhan JR, Costas L, Dal Maso L, et al. Postmenopausal hormone therapy and non-Hodgkin lymphoma: a pooled analysis of InterLymph case-control studies. Ann Oncol (2013) 24(2):433-41. doi:10.1093/annonc/mds340

124. Costas L, Lambert BH, Birmann BM, Moysich KB, De Roos AJ, Hofmann JN, et al. A pooled analysis of reproductive factors, exogenous hormone use, and risk of multiple myeloma among women in the International Multiple Myeloma Consortium. Cancer Epidemiol Biomarkers Prev (2016) 25(1): 217-21. doi:10.1158/1055-9965.epi-15-0953

125. Carreras-Torres R, Johansson M, Gaborieau V, Haycock PC, Wade KH, Relton CL, et al. The role of obesity, type 2 diabetes, and metabolic factors in pancreatic cancer: a Mendelian Randomization Study. J Natl Cancer Inst (2017) 109(9). doi:10.1093/jnci/djx012

126. Vanderweele TJ, Vansteelandt $\mathrm{S}$. Odds ratios for mediation analysis for a dichotomous outcome. Am J Epidemiol (2010) 172(12):1339-48. doi:10.1093/ aje/kwq332

127. Baris D, Zahm SH. Epidemiology of lymphomas. Curr Opin Oncol (2000) 12(5):383-94. doi:10.1097/00001622-200009000-00002

Conflict of Interest Statement: The authors declare that the research was conducted in the absence of any commercial or financial relationships that could be construed as a potential conflict of interest.

The reviewer JS and the handling Editor declared their shared affiliation.

Copyright (c) 2018 Hosgood, Gunter, Murphy, Rohan and Strickler. This is an openaccess article distributed under the terms of the Creative Commons Attribution License (CC BY). The use, distribution or reproduction in other forums is permitted, provided the original author(s) and the copyright owner are credited and that the original publication in this journal is cited, in accordance with accepted academic practice. No use, distribution or reproduction is permitted which does not comply with these terms. 